\title{
The role of intraoperative videoangiography in aneurysm surgery-a comparative study from a tertiary care hospital
}

\author{
K. Kaiser, M. Nayil", A. Ramzan, S. Sarbjit, W. Abrar, A. Sajad and A. Rashid
}

\begin{abstract}
Background: Indocyanine green (ICG) is a near-infrared (NIR) fluorescent dye. After intravenous injection, it reaches the vessels of the brain within $30 \mathrm{~s}$. A real-time visualization of the cerebral vasculature is possible.

Results: The infarction rate and the postoperative rebleed rate in the pre-ICG era group were higher than in the ICG era.

Conclusion: Intraoperative ICGVA is a safe and effective method to confirm the exclusion of the clipped aneurysm from the circulation. It also helps to assess the patency of the surrounding vessels.

Keywords: Aneurysm, Subarachnoid bleed, Clip repositioning, Indocyanine green, ICG, Intra-op videoangiography, Stroke, Infarction, Rebleed
\end{abstract}

\section{Introduction}

Indocyanine green dye, a negatively charged tricarbocyanine dye, was approved for clinical use in 1956. The dye is excreted unaltered via the liver. Its administration is safe with a very minimal incidence of major or minor complications. After intravenous injection, it gets quickly bound to plasma-proteins and reaches the brain vessels within $30 \mathrm{~s}$. A real-time visualization of vessel flow and aneurysm filling within the surgical field is the greatest advantage of the dye $[1,2]$. This property of Indocyanine green dye is being widely utilized intraoperatively to assess the completeness of exclusion of aneurysm from the circulation and inadvertent clipping of parent vessels and perforators which clinically translates as reduced rebleeding and ischemic stroke rates [3, 4]. The purpose of our study was to know the impact of ICG videoangiography on the operative outcome of aneurysm surgery.

\footnotetext{
* Correspondence: nayilkhursh@gmail.com

Department of Neurosurgery, Sheri-Kashmir-Institute of Medical Sciences, Kashmir 190011, India
}

\section{Springer Open}

(c) The Author(s). 2021 Open Access This article is licensed under a Creative Commons Attribution 4.0 International License, which permits use, sharing, adaptation, distribution and reproduction in any medium or format, as long as you give appropriate credit to the original author(s) and the source, provide a link to the Creative Commons licence, and indicate if changes were made. The images or other third party material in this article are included in the article's Creative Commons licence, unless indicated otherwise in a credit line to the material. If material is not included in the article's Creative Commons licence and your intended use is not permitted by statutory regulation or exceeds the permitted use, you will need to obtain permission directly from the copyright holder. To view a copy of this licence, visit http://creativecommons.org/licenses/by/4.0/.

\section{Methods}

This was a prospective study conducted in the Department of Neurosurgery, Sher-I-Kashmir institute of medical sciences (SKIMS), Kashmir, India. The study period lasted from January 2014 to December 2018 (5 years). All patients who were operated for aneurysm clipping were enrolled in this study. There were 332 patients in this arm. Each patient was assessed for perioperative stroke, defined here as a new permanent or transient neurological deficit within $72 \mathrm{~h}$ of surgery with an appropriate image correlate on CT scan. This group was compared with the 5-year (2009-2013) data of our patients who were operated by us in the department when an intraoperative ICG facility was not available to us. We retrospectively retrieved the records of these patients. There were 353 patients in this arm. The stroke rates and rebleed rates within the hospital for both these groups were compared. As per the protocol in our department, all posterior circulation aneurysms are coiled; hence, the study included only anterior circulation aneurysms. This study was approved by the Institutional Ethics Committee of Sher-i- 
Kashmir Institute of Medical Sciences, under reference number 14/2014 of IEC-SKIMS. A written consent to participate in the study was taken from the patient or next of kin. For indocyanine green videoangiography (ICG-VA), a bolus of $25 \mathrm{mg}$ of ICG dye (Aurogreen, Aurolab, Madurai) was injected via a peripheral vein. For visualization, the Zeiss Pentero operating microscope (Carl Zeiss $\mathrm{GmbH}$ ) with integrated near-infrared ICG angiography (IR800) was used. Intraoperative ICG-VA was performed in all patients without complications. In cases in which parent or branching vessel stenosis or residual aneurysm necks were identified with ICG-VA, the clip position was changed or additional clips were applied and another ICG-VA was performed. We calculated the adequacy of our sample size by logging on to www.sealedenvelope.com. The statistical significance level, alpha, was kept at 5\% (0.05) and adequate power for a trial was kept at $0.9(90 \%)$. The sample size needed to obtain the results was 130 in each arm as shown in Fig. 1. We had more than 300 patients in each arm. Our sample size was more than adequate.

\section{Results}

\section{Demography}

The mean age of patients in the pre-ICG era and the post-ICG era was 60.3 years and 61.1 years, respectively. A female predominance was seen in both the study groups. Both groups were comparable in their demographic and clinical profile (Table 1).

\section{Surgical procedure and postoperative stroke outcome} In the ICG group, we clipped 364 aneurysms in 332 patients, and in the pre-ICG group, we clipped 381 aneurysms in 353 patients.

The infarction rate in the pre-ICG era group was 5.77.\% $(22 / 381)$, and it was $1.09 \%(4 / 364)$ in the ICG era; the difference was statistically significant $(P=0.0005)$. The clip readjustment rate for maintaining the patency of the distal vessels was $1.92 \%(7 / 364)$ and the clip readjustment rate for achieving complete aneurysm occlusion was $4.67 \%$ (17/364). The postoperative rebleed rate was seen in 5 patients of the pre-ICG group and there was no rebleed rate in the ICG group (1.3\% vs 0 , Table 1$)$.

\section{Discussion}

Indocyanine green videoangiography (ICG-VA) has over the last few years become a standard practice of evaluating the blood flow in cerebral vasculature during aneurysm surgery. Also, its utility has broadened to confirming the patency of collateral circulation during surgery for complex vascular and neoplastic lesions of brain and during extracranial-intracranial bypass surgery [1-4]. In comparison to intraoperative DSA, swiftness of image acquisition is a definite advantage of ICG-VA. This allows the surgeon to manipulate the surgical field during surgery. Another advantage of ICG over DSA is the improved resolution to assess small perforating arteries which translates into reduced postoperative ischemic deficits [5]. As the rates of detecting residual aneurysm dome filling or parent vessel stenosis have markedly increased intraoperatively after the administration of ICG, the rates of repositioning or addition of aneurysm clips have increased [6, 7]. We did not find any difference between clip adjustment rates of different sites of aneurysms after ICG administration which has been noted in other studies also [8]. The incidence of perioperative ischemic stroke in our study did differ significantly between eras, $1.09 \%$ for ICG and 5.77\% for pre ICG era. In our study, the intraoperative use of ICG made us to reposition the clip in 6.59\% (24/364) patients which manifested clinically as a reduced rate of ischemic stroke. In other large surgical series, the clip

\section{Significance level (alpha) \\ Power (1-beta) \\ Percentage 'success' in control group \\ Percentage 'success' in experimental group} Calculate sample size

Sample size required per group Total sample size required

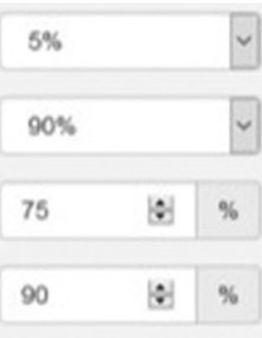

130

260
You could say:

260 patients are required to have a $90 \%$ chance of detecting, as significant at the $5 \%$ level, an increase in the primary outcome measure from $75 \%$ in the control group to $90 \%$ in the experimental group.

Fig. 1 Shows the minimal sample size required to draw inference 
Table 1 Showing the demographics and clinico-radiological profile of our patients

\begin{tabular}{llll}
\hline & Pre-ICG era & ICG era \\
\hline Demographics & & & \\
No. of patients & 353 & 332 & \\
Aneurysms clipped & 381 & 364 \\
Mean age (years) & 60.3 & 61.1 \\
Gender ratio (F:M) & $1.29: 1(199:$ & $1.25: 1(185:$ & \\
& $154)$ & $147)$ & \\
Clinical profile & & & \\
Headache & $89.25 \%$ & $88.25 \%$ & \\
Altered sensorium & $43.62 \%$ & $42.77 \%$ & \\
Seizures & $30.59 \%$ & $29.81 \%$ & \\
Weakness of limbs & $31.72 \%$ & $30.42 \%$ & \\
Site of aneurysms & $\boldsymbol{n}(\%)$ & $\boldsymbol{n}(\%)$ & \\
Acom & $171(44.9)$ & $162(44.5)$ & \\
MCA & $143(37.5)$ & $136(37.4)$ & \\
Pcom & $22(5.8)$ & $19(5.2)$ & \\
Ophthalmic & $16(4.2)$ & $15(4.1)$ & \\
ICA & $15(3.9)$ & $14(3.8)$ & \\
DACA & $14(3.7)$ & $18(5)$ & \\
Overall clip repositioning & NA* & $24 / 364$ & \\
& & $(6.59 \%)$ & \\
Clip repositioning for patency of & & $7 / 364$ & \\
vessels & & $(1.92 \%)$ & \\
Clip repositioning for aneurysm & & $17 / 364$ & \\
exclusion & & $(4.67 \%)$ & \\
Periop stroke & $22 / 381$ & $4 / 364$ & \\
& $(5.77 \%)$ & $(1.09 \%)$ & $0.0005 * *$ \\
Post-op rebleed from the clipped & $5 / 381(1.3 \%)$ & $0 / 364(0 \%)$ & $P=$ \\
aneurysm & & & $0.062 * * *$ \\
\hline
\end{tabular}

*NA not applicable

** Statistically significant

***Statistically not significant

adjustment rates range between $2 \%$ and $38 \%$ (Table 2) [4, 8]. The wide variation in clip adjustment rates is because of a low number of patients in some studies, inhomogeneous patient groups, and the non-systematic application of the technique.

In our study, the rebleed rates also differed between the two groups. The rebleed rate in the pre-ICG era was $1.3 \%$ and no patient in the ICG group had a rebleed from the clipped aneurysm. The difference however was not statistically significant. Same rebleed rates have been reported from follow-up of ISAT trial patients and other studies $[20,21]$. The low rebleed rate is because ICGVA allows checking for residual aneurysm filling and repositioning of the clips across the neck of the aneurysm; however, there are aneurysms where ICGVA will show a totally excluded aneurysm but intra-op needle puncture of the aneurysm will aspirate blood as was reported by Roessler et al. [4] in 2 out of 232 patients (0.8\%) (falsenegative cases). In comparison to intra-op DSA, ICG angiography can be repeated many times during a single
Table 2 Literature summary of intraoperative clip adjustment rates after ICG-VA

\begin{tabular}{|c|c|c|c|}
\hline $\begin{array}{l}\text { Authors } \\
\text { and year }\end{array}$ & $\begin{array}{l}\text { No. of patients } \\
\text { undergoing } \\
\text { ICG-VA }\end{array}$ & $\begin{array}{l}\text { Clip } \\
\text { adjustment } \\
\text { rate (\%) }\end{array}$ & $\begin{array}{l}\text { Aneurysm remnants } \\
\text { on intra-op/post-op } \\
\text { DSA (\%) }\end{array}$ \\
\hline $\begin{array}{l}\text { Raabe et al., } \\
2003 \text { [1] }\end{array}$ & 14 & 7.1 & NA \\
\hline $\begin{array}{l}\text { Raabe et al., } \\
2005 \text { [2] }\end{array}$ & 114 & 9 & NA \\
\hline $\begin{array}{l}\text { Imizu et al., } \\
2008 \text { [9] }\end{array}$ & 13 & 38 & 61 \\
\hline $\begin{array}{l}\text { Li et al., } \\
2009 \text { [10] }\end{array}$ & 120 & 4.6 & NA \\
\hline $\begin{array}{l}\text { Ma et al., } \\
2009 \text { [11] }\end{array}$ & 45 & 4.4 & 6.7 \\
\hline $\begin{array}{l}\text { Dashti et al., } \\
2009 \text { [12] }\end{array}$ & 190 & 12 & 6 \\
\hline $\begin{array}{l}\text { Jing et al., } \\
2010 \text { [13] }\end{array}$ & 42 & 5 & 2 \\
\hline $\begin{array}{l}\text { Wang et al., } \\
2010 \text { [14] }\end{array}$ & 129 & 2 & NA \\
\hline $\begin{array}{l}\text { Fischer } \\
\text { et al., } 2010 \\
\text { [15] }\end{array}$ & 50 & 10 & 6 \\
\hline $\begin{array}{l}\text { Gruber } \\
\text { et al., } 2011 \\
\text { [16] }\end{array}$ & 104 & 6.7 & NA \\
\hline $\begin{array}{l}\text { Oda et al., } \\
2011 \text { [17] }\end{array}$ & 39 & 10 & 10 \\
\hline $\begin{array}{l}\text { Washington } \\
\text { et al., } 2013 \\
\text { [7] }\end{array}$ & 49 & 4.1 & 6.1 \\
\hline $\begin{array}{l}\text { Özgiray } \\
\text { et al., } 2013 \\
\text { [18] }\end{array}$ & 109 & 1.8 & 3.6 \\
\hline $\begin{array}{l}\text { Moon et al., } \\
2013 \text { [19] }\end{array}$ & 127 & 6.3 & 4.7 \\
\hline $\begin{array}{l}\text { Roessler } \\
\text { et al., } 2014 \\
{[4]}\end{array}$ & 232 & 9.1 & 4.5 \\
\hline $\begin{array}{l}\text { Hardesty } \\
\text { et al.,2014 } \\
\text { [8] }\end{array}$ & 79 & 5 & NA \\
\hline $\begin{array}{l}\text { Current } \\
\text { study }\end{array}$ & 332 & 6.59 & NA \\
\hline
\end{tabular}

NA not available

surgical procedure as it is easy to perform and carries a very low risk of complication. In contrast, intraoperative DSA is time-consuming, and it interrupts the surgery. However, we do agree that intraoperative DSA remains the most reliable intraoperative tool for excluding an incompletely clipped aneurysm because ICGVA is limited by the field of the operating microscope, presence of clot, calcification, or overlapping blood vessel or brain tissue. All these factors are not an issue in DSA [7, 22]. The purpose of our study was to evaluate the overall 
outcomes achieved in each era and to highlight the impact of intra-op ICG videoangiography. We found a $1.92 \%$ rate of clip replacement due to parent vessel stenosis or perforator occlusion and a $4.67 \%$ rate of residual perfusion of the aneurysm dome or neck leading to additional clip application (Figs. 2 and 3). Therefore, we concluded that nearly one in six patients benefits from the use of intraoperative ICGVA. We excluded strokes that were actually due to cerebral vasospasm by only including deficits which occurred within $72 \mathrm{~h}$ of surgery with an appropriate imaging correlate. At the same time, we do believe that some patients with subarachnoid hemorrhage would present with vasospasm immediately postoperatively, and therefore, the strokes reported here may include events not directly related to surgical compromise. However, since the two groups were well balanced, we believe that the frequency of such events would have been equal or near equal and hence would cancel each other. All said we do believe that ICGVA is not a replacement for DSA in all cases as intraoperative DSA still has a key role in aneurysm surgery. ICGVA is limited by the field of view of the operative microscope, only the dissected and thus visible vascular structures within the operative field can be visualized, and at times, it is not possible to assess the arteries if obscured by cisternal blood, aneurysm, or aneurysm clip. Also, patients
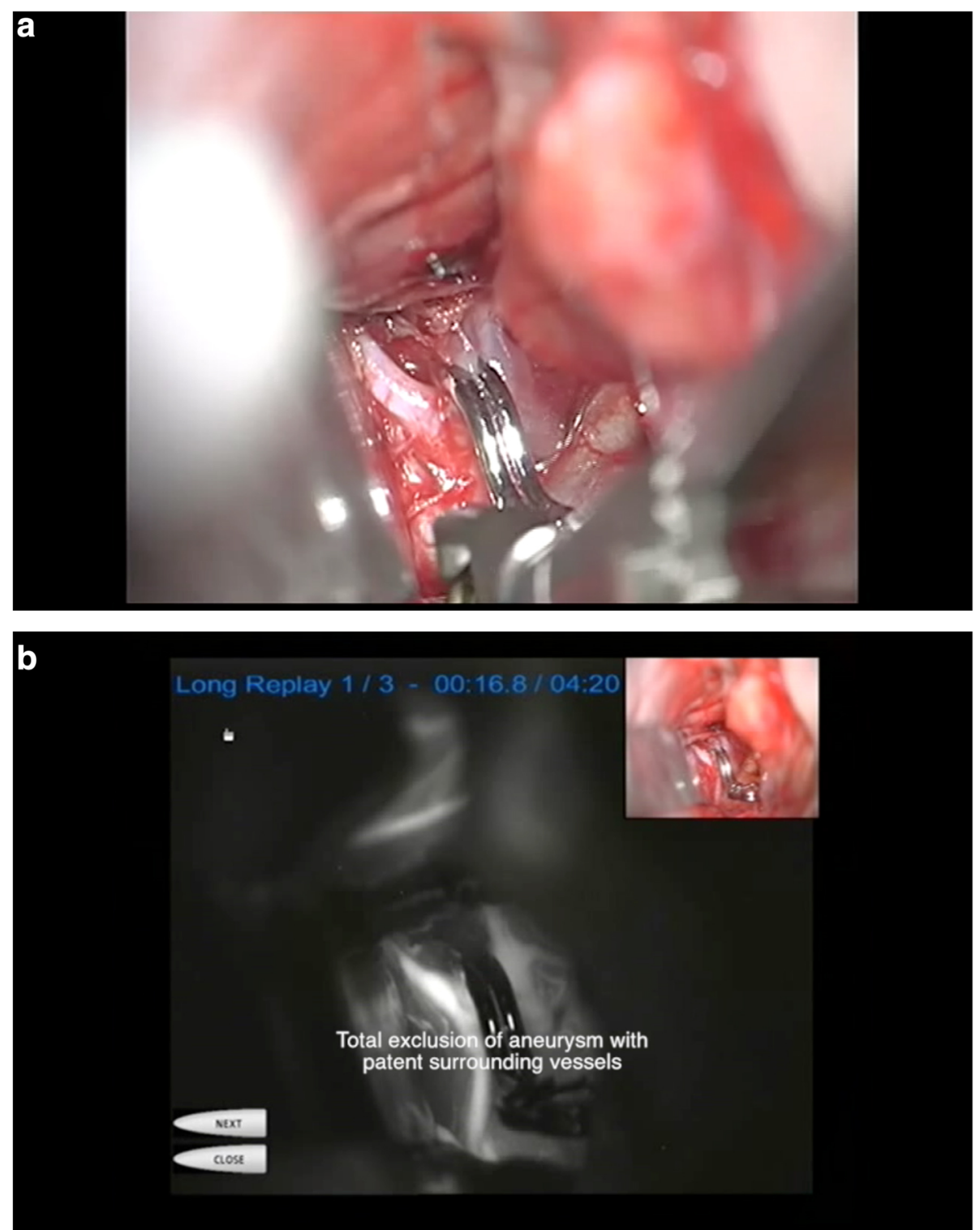

Fig. 2 a Intra-op photo which shows the aneurysm clip across the neck of Acom aneurysm. $\mathbf{b}$ Intra-op photo taken after ICG injection shows non-opacification of the Acom aneurysm with patent surrounding vessels 

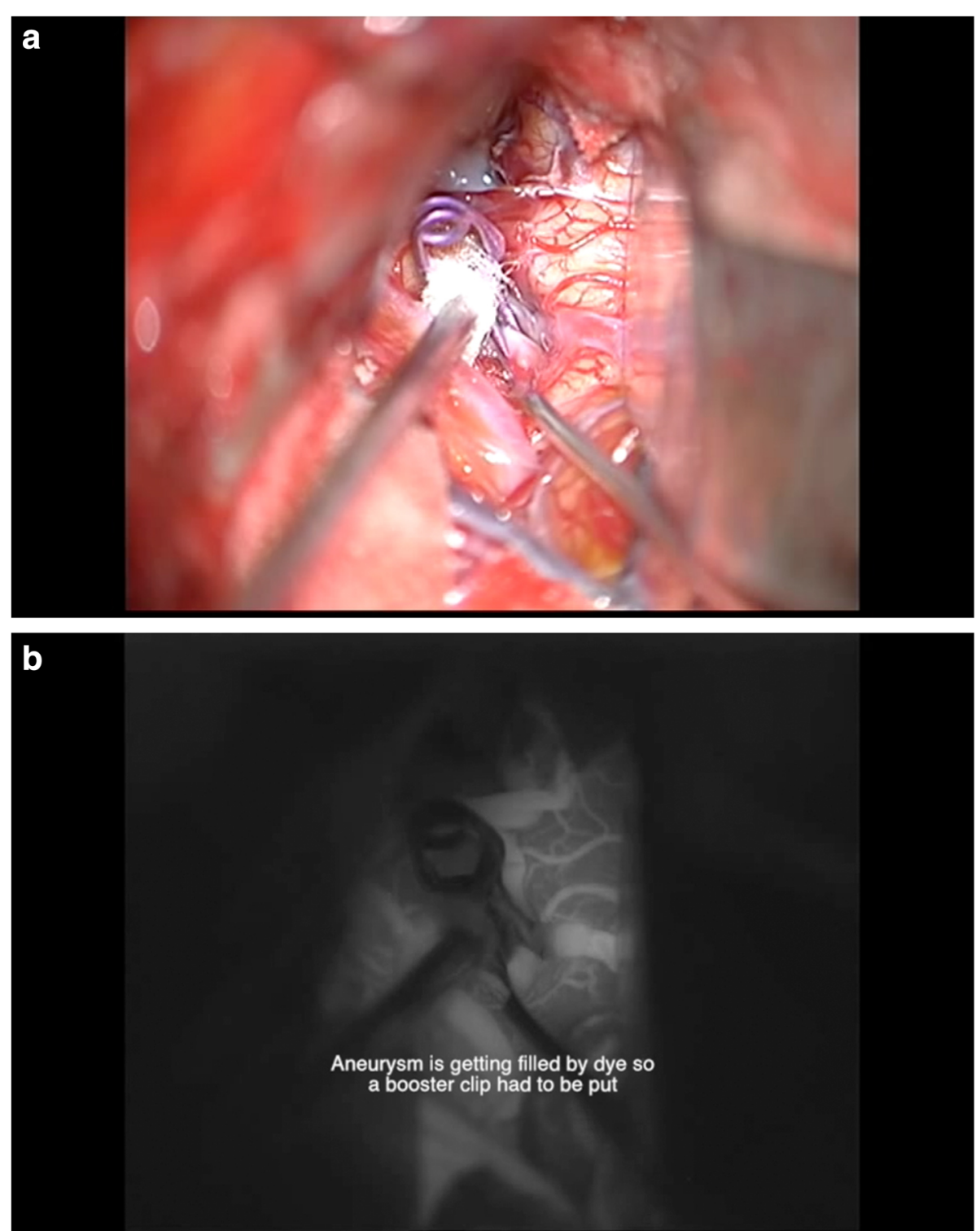

Fig. 3 a Intra-op photo which shows the aneurysm clip across the neck of MCA aneurysm. $\mathbf{b}$ Intra-op photo taken after ICG injection shows filling of the clipped MCA aneurysm

with calcified vessels or partially thrombosed aneurysms are best assessed by intraoperative DSA. However, intraoperative DSA remains itself an imperfect modality with up to $5-8 \%$ rate of unexpected vessel stenosis or aneurysm filling compared to the gold standard of postoperative DSA. Literature reports that postoperative imaging, either CTA or DSA, is required to fully evaluate the status of the vessel even after intraoperative DSA [10, 12, 23-25]. We follow our patients routinely with postoperative CTA with selective use of postoperative DSA. A combination of intra-op ICG videoangiography and postoperative DSA/CTA is a must in aneurysm surgery to improve patient outcome.

\section{Strengths and limitations of our study}

The robustness of our study lies in the high number of patients. This made us capable to achieve a reliable sensitivity of this technique. The major limitation of our study is that we have not answered a common question whether post-op DSA is warranted for those patients who have a satisfactory intra-op result on ICGVA as we have done post-op DSA only in a limited number of patients.

\section{Conclusion}

Intraoperative ICGVA is a safe and effective modality to know about the exclusion of the aneurysm from the circulation and also to maintain the patency of parent vessels and perforators. 


\section{Abbreviations}

ICG: Indocyanine green; NIR: Near-infrared; ICGVA: Indocyanine green videoangiography

\section{Supplementary Information}

The online version contains supplementary material available at https://doi. org/10.1186/s41984-021-00106-0.

\section{Additional file 1: Video 1. \\ Additional file 2: Video 2}

\section{Acknowledgements}

We thank Mr Irshad for his typographical assistance.

\section{Authors' contributions}

All authors have read and approved the manuscript. KK, acquisition and analysis. NM, concept and design. AR, acquisition and analysis. SS, drafting the work. AW, revising the work. SA, drafting the work. RA, revising the work.

\section{Authors' information}

The corresponding author NM is a professor of Neurosurgery with interest in Neurovascular surgery.

\section{Funding}

Nil.

\section{Availability of data and materials}

NA.

\section{Declarations}

Ethics approval and consent to participate

This study was approved by the Institutional Ethics Committee of SKIMS. The reference number is 14/2014 of IEC-SKIMS. A written consent to participate in the study was taken from the patient or next of kin.

\section{Consent for publication}

NA.

\section{Competing interests}

The authors declare that they have no competing interests.

Received: 14 September 2020 Accepted: 15 April 2021

Published online: 09 August 2021

\section{References}

1. Raabe A, Beck J, Gerlach R, Zimmermann M, Seifert V. Near-infrared indocyanine green video angiography: a new method for intraoperative assessment of vascular flow. Neurosurgery. 2003;52(1):132-9. https://doi. org/10.1097/00006123-200301000-00017.

2. Raabe A, Nakaji P, Beck J, Kim LJ, Hsu FP, Kamerman JD, et al. Prospective evaluation of surgical microscope-integrated intraoperative near-infrared indocyanine green videoangiography during aneurysm surgery. J Neurosurg. 2005;103(6):982-9. https://doi.org/10.3171/jns.2005.103.6.0982.

3. Chiang VL, Gailloud P, Murphy KJ, Rigamonti D, Tamargo RJ. Routine intraoperative angiography during aneurysm surgery. J Neurosurg. 2002; 96(6):988-92. https://doi.org/10.3171/jns.2002.96.6.0988.

4. Roessler K, Krawagna M, Dorfler A, Buchfelder M, Ganslandt O. Essentials in intraoperative indocyanine green videoangiography assessment for intracranial aneurysm surgery: conclusions from 295 consecutively clipped aneurysms and review of the literature. Neurosurgery Focus. 2014;36(2):E7. https://doi.org/10.3171/2013.11.FOCUS13475.

5. Wang S, Liu L, Zhao Y, Zhang D, Yang M, Zhao J. Evaluation of surgical microscope-integrated intraoperative near-infrared indocyanine green video angiography during aneurysm surgery. Neurosurg Rev. 2011;34(2):209-15. https://doi.org/10.1007/s10143-010-0305-2.

6. Payner TD, Horner TG, Leipzig TJ, Scott JA, Gilmor RL, DeNardo AJ. Role of intraoperative angiography in the surgical treatment of cerebral aneurysms. J Neurosurg. 1998:88(3):441-8. https://doi.org/10.3171/jns.1998.88.3.0441.
7. Washington CW, Zipfel GJ, Chicoine MR, Derdeyn CP, Rich KM, Moran CJ, et al. Comparing indocyanine green video angiography to the gold standard of intraoperative digital subtraction angiography used in aneurysm surgery. J Neurosurg. 2013;118(2):420-7. https://doi.org/10.3171/2012.10.JNS11818.

8. Hardesty DA, Thind H, Zabramski JM, Spetzler RF, Nakaji P. Safety, efficacy, and cost of intraoperative indocyanine green angiography compared to intraoperative catheter angiography in cerebral aneurysm surgery. J Clin Neurosci. 2014;21(8):1377-82. https://doi.org/10.1016/j.jocn.2014.02.006.

9. Imizu S, Kato Y, Sangli A, Oguri D, Sano H. Assessment of incomplete clipping of aneurysms intraoperatively by a nearinfrared indocyanine greenvideo angiography (Niicg-Va) integrated microscope. Minim Invasive Neurosurg. 2008;51:199-203.

10. Li J, Lan Z, He M, You C. Assessment of microscopic-integrated indocyanine green angiography during intracranial aneurysm surgery: a retrospective study of 120 patients. Neurol India. 2009;57(4):453-9. https:/doi.org/10.4103/0028-3886.55607.

11. Ma CY, Shi JX, Wang HD, Hang CH, Cheng HL, Wu W. Intraoperative indocyanine green angiography in intracranial aneurysm surgery: Microsurgical clipping and revascularization. Clin Neurol Neurosurg. 2009;111:840-6.

12. Dashti $R$, Laakso A, Niemelä M, Porras M, Hernesniemi J. Microscopeintegrated near-infrared indocyanine green videoangiography during surgery of intracranial aneurysms: the Helsinki experience. Surg Neurol. 2009:71(5):543-50. https://doi.org/10.1016/j.surneu.2009.01.027.

13. Jing Z, Ou S, Ban Y, Tong Z, Wang Y. Intraoperative assessment of anterior circulation aneurysms using the indocyanine green video angiography technique. J Clin Neurosci. 2010;17:26-8

14. Wang S, Liu L, Zhao Y, Zhang D, Yang M, Zhao J. Evaluation of surgical microscope-integrated intraoperative near-infrared indocyanine green videoangiography during aneurysm surgery. Neurosurg Rev. 2010;34:209-15.

15. Fischer G, Stadie A, Oertel JM: Near-infrared indocyanine green videoangiography versus microvascular Doppler sonography in aneurysm surgery. Acta Neurochir (Wien). 2010;152:1519-25.

16. Gruber A, Dorfer C, Bavinzski G, Standhardt H, Ferraz-Leite H, Knosp E. Superselective indocyanine green angiography for selective revascularization in the management of peripheral cerebral aneurysms. AJNR Am J Neuroradiol. 2012;33:E36-E37.

17. Oda J, Kato Y, Chen SF, Sodhiya P, Watabe T, Imizu S, et al. Intraoperative near-infrared indocyanine green-videoangiography (ICG-VA) and graphic analysis of fluorescence intensity in cerebral aneurysm surgery. J Clin Neurosci. 2011;18:1097-1100.

18. Özgiray E, Aktüre E, Patel N, Baggott C, Bozkurt M, Niemann D, et al. How reliable and accurate is indocyanine green video angiography in the evaluation of aneurysm obliteration? Clin Neurol Neurosurg. 2013;115:870-8.

19. Moon HS, Joo SP, Seo BR, Jang JW, Kim JH, Kim TS. Value of indocyanine green videoangiography in deciding the completeness of cerebrovascular surgery. J Korean Neurosurg Soc. 2013;53:349-55.

20. Alshekhlee A, Mehta S, Edgell RC, Vora N, Feen E, Mohammadi A, et al. Hospital mortality and complications of electively clipped or coiled unruptured intracranial aneurysm. Stroke. 2010;41(7):1471-6. https://doi. org/10.1161/STROKEAHA.110.580647.

21. Molyneux AJ, Birks J, Clarke A, Sneade M, Kerr RSC. The durability of endovascular coiling versus neurosurgical clipping of ruptured cerebral aneurysms: 18 year follow-up of the UK cohort of the International Subarachnoid Aneurysm Trial (ISAT). Lancet. 2015;385(9969):691-7.

22. Tang G, Cawley CM, Dion JE, Barrow DL. Intraoperative angiography during aneurysm surgery: a prospective evaluation of efficacy. J Neurosurg. 2002; 96(6):993-9. https://doi.org/10.3171/jns.2002.96.6.0993.

23. Katz JM, Gologorsky Y, Tsiouris AJ, Wells-Roth D, Mascitelli J, Gobin YP, et al. Is routine intraoperative angiography in the surgical treatment of cerebral aneurysms justified? A consecutive series of 147 aneurysms. Neurosurgery. 2006;58(4):719-27. https://doi.org/10.1227/01.NEU.0000204316.49796.A3.

24. Klopfenstein JD, Spetzler RF, Kim LJ, Feiz-Erfan I, Han PP, Zabramski JM, et al. Comparison of routine and selective use of intraoperative angiography during aneurysm surgery: a prospective assessment. J Neurosurg. 2004; 100(2):230-5. https://doi.org/10.3171/jns.2004.100.2.0230.

25. Kumar R, Friedman JA. Intraoperative angiography during cerebral aneurysm surgery. Neurocrit Care. 2009;11(2):299-302. https://doi.org/10.1 007/s12028-009-9229-5.

\section{Publisher's Note}

Springer Nature remains neutral with regard to jurisdictional claims in published maps and institutional affiliations. 